Available online at

\title{
Mapping of Landslide Susceptible Zones by Using Frequency Ratios at Bluncong Subwatershed, Bondowoso Regency
}

\author{
D. Efendi ${ }^{1}$, E. Hidayah ${ }^{2 *}$, A. Hasanuddin ${ }^{3}$. \\ 1,2*3 Master Program in Civil Engineering, Department of Civil Engineering, Faculty of Engineering, \\ University of Jember \\ Email:2*entin.teknik@unej.ac.id
}

\begin{tabular}{|c|c|}
\hline \multicolumn{2}{|c|}{ Article History : } \\
\hline Article entry & : 12-01-2021 \\
\hline Article revised & :29-01-2021 \\
\hline Article received & $: 04-02-2021$ \\
\hline
\end{tabular}

Keywords :

Bluncong, DEM, Frequency Ratio, Landslide, Satellite Images.

IEEE Style in citing this article:

[1] Y. Wang, Q. Lin, and P. Shi,

'Spatial pattern and influencing

factors of landslide casualty

events', J. Geogr. Sci., vol. 28,

no. 3, pp. 259-274, 2018, doi:

10.1007/s11442-018-1471-3.

\begin{abstract}
A B S T R A C T
Landslides are the disasters that frequently happen in the Bluncong sub-watershed. These incidents have caused damage and malfunction of road infrastructure, bridges, and irrigation buildings. Therefore, it is important to anticipate landslides through the mapping of landslide-susceptibility areas. This study aims to map landslide susceptibility at Bluncong sub watershed, Bondowoso, by using a Geographical Information System and remote sensing. The landslide susceptibility analysis and mapping are conducted based on landslide occurrences with the Frequency Ratio approach. The landslide sites are identified from field survey data interpretation. Digital Elevation Model maps, geological data, land uses and rivers data, and Landsat 8 images are collected, processed, and then built into the GIS platform's spatial database. The selected factors that cause landslide occurrences are land use, distance to the river, aspect, slope, elevation, curvature, and the vegetation index (NDVI). The results show that the accuracy of the map is acceptable. The frequency ratio model gained the area under curve (AUC) value of 0.79 . It is found that $9.08 \%$ of the area has very high landslide susceptibility. Local governments can use this study's mapping results to minimize the risk at landslidesusceptible zones.
\end{abstract}

\section{Introduction}

Landslide disaster is one of the most frequent disasters in Indonesia. The landslides' hazards pose a threat to social and economic development and the environment [1]. The landslides' social-economic impacts include hindrance of transportation access due to blocked roads, shortage of irrigation water due to broken irrigation channels. Environmental impacts include damage to local residents' croplands. Hence, the landslides have had significant impacts on the income sources of the local community and residents. The high costs must be 
incurred for rehabilitation and maintenance afterward [2].

Identification of a landslide area is an important step to analyze the relationship between the landslide location and factors such as geological and geomorphological factors and the land-use factor of the area. It can be expected that based on the analysis, any type of land use suitable for land with particular characteristics and geological factors can be understood [3][4][5]. Further, based on the landslide occurrences, map modeling on landslides can be generated to manage the landslide risks and impacts and minimize the material or immaterial damages caused by the landslides.

Nowadays, various methods and techniques have been used to analyze landslide susceptibility zones. Studies have been conducted to value the landslides' susceptibility by using Analytical Hierarchy Process and spatial geographical information system modeling in Aceh Tenggara regency [6], and in Sarv-Abad, Kurdistan, Iran [4]. AHP method is a means of making complex, unstructured, multi-criteria decisions. However, the weighting process in AHP enables objective as well as subjective considerations in decision making so that it is weakly reliable [7]. Many landslide zoning methods have been applied by using the Frequency Ratio. This method is simple but can result in sufficiently high accuracy [8], [9]. The frequency ratio approach is a quantitative technique for landslide susceptibility assessment using GIS techniques and spatial data [10]. This approach is based on a measurable relationship between the landslide inventory and the factors causing landslides to be effective.

Landslides occur almost annually in Bluncong subwatershed in the rainy season during high-intensity rains. In light of the landslides in the Bluncong subwatershed, this research focuses on landslide zones mapping as an effort of disaster mitigation. Valuation of landslide vulnerability in this research is conducted using the Frequency Ratio (FR) that makes the use of eight factors that cause the landslides. The factors used in this study to analyze the landslide vulnerability include geomorphological and geological characteristics, land use, and vegetation index. The accuracy of the model is assessed by comparing the model prediction with actual landslide frequency. The comparison is shown in a Receiver Operating Curve (ROC) graph. Factors having significant effects on landslides are also identified. 


\section{Area of Study}

Bluncong subwatershed is located in the Klabang subdistrict. It is one of the areas vulnerable to landslides in the Bondowoso Regency. In addition to rains and floods, productive sand mining practices by residents in the rivers are likely to be the driving factors of the landslides.

Based on Google Earth map and field surveys, 48 locations have been identified as the sites where landslides have ever occurred. It is also found that the total area of Bluncong subwatershed is 3578.76 hectares. Most of the landslide sites are located in the river's vicinity, as shown in Figure 1. Materials involved in the landslides in this area are soil, sand, and rocks due to rock discontinuity along the joints, crevices, and rock strata, and some areas with steep slopes.

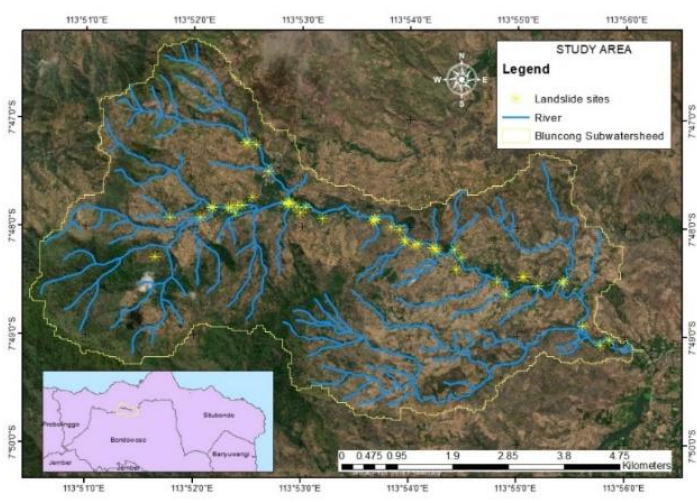

Figure 1. Area of Study

\section{Research Method}

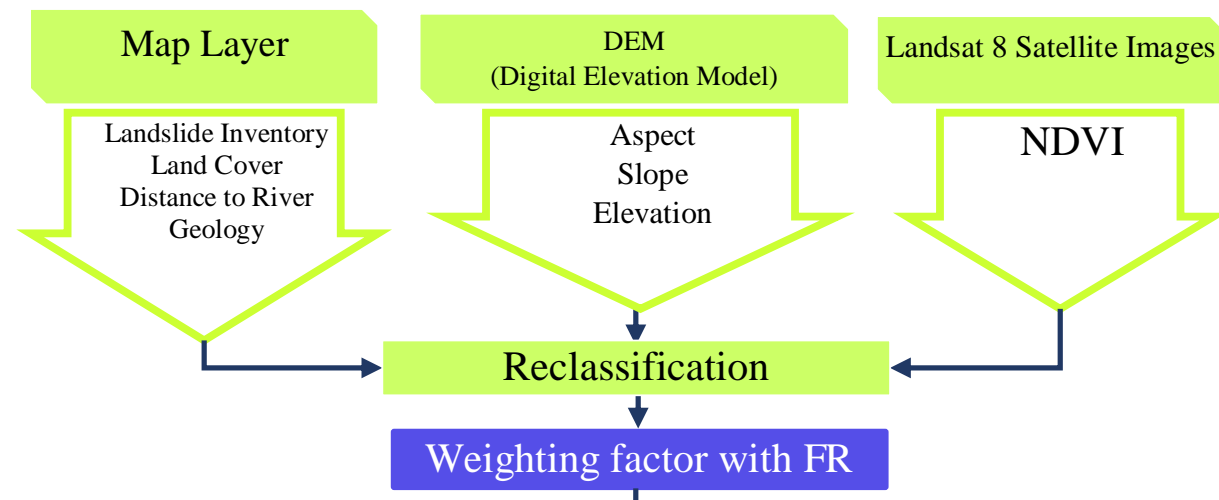

Overlay for Obtaining Landslide Susceptibility Map and determining

Validating the Model by Comparing the Model Against

\section{LANDSLIIDE SUSCEPTIBILITYY}

Figure 2. The stages of the research 
The methodology used in this study is presented in the stages in Figure 2. The stages of the research are: (1) data preparation and reclassification of the drivers of the landslides, and creating an inventory of the landslides and surveying the landslide sites (2) weighting the factors by using the FR method (3) computing the landslide susceptibility index by using FR method, and (4) counting validation modeling, (5)

\subsection{Data Preparation and Reclassification}

According to a number of published studies on landslide susceptibility, landslides are driven by many factors. Landslides are a complex natural disaster that depends on the soil's geological and geomorphological characteristics, the land use, and the land covers. Considering geographical features of the study area and the results of some previous studies that have acceptably accurate results, the following eight parameters as the main factors that affect the landslides, namely: land use, slope aspect, distance to the river, slope, elevation, NDVI, geology, and curvature [8][11][12][13].

\subsubsection{Land use (LU)}

Landuse has an essential role in slope stability. Lands covered by the forest govern water continuously and steady water infiltration. In contrast, agricultural lands affect slope stability due to the covered lands' saturation [14]. Thematic maps on land use have been provided by RBI Jatim (Topographical Map of Indonesia: Jawa Timur Province) 2009. Six uses of the land in the area are forest, garden, field, settlement, rice field, dan shrubs.

\subsubsection{Slope Aspect (SA)}

The slope aspect results from DEM SRTM with a grid size of $30 \mathrm{~m} \times 30 \mathrm{~m}$ and is defined as the direction of the field surface's maximum slope. The slope aspect strongly influences physiography, the direction of main rainfall, and land erosion [15].

\subsubsection{Distance to the River (DR)}

This factor has an important role as a driving factor of the landslides[16]. Thematic maps on the distance to the river have been provided by RBI Jatim (Topographical Map of Indonesia: Jawa Timur Province) 2009. The distance to the river is determined by creating a buffer on the river on the map. The source of the data is the thematic map of river networks. 


\subsubsection{Slope gradient $(\mathbf{S})$}

It is one of the causes of the instability of the slope[17] [18]. The moisture content and pore pressure could be influenced at local scales. In contrast, slope angle patterns could control the regional hydraulic behavior at larger scales[19]. Semakin. The slope angle in the area of study varies between $0^{\circ}$ to $58^{\circ}$. The map is automatically produced in GIS by using DEM SRTM with a grid size of $30 \mathrm{~m} \times 30 \mathrm{~m}$.

\subsubsection{Elevation $(E)$}

The elevation is often indirectly used as a factor that triggers the landslides [20]. The elevation is identified by using DEM SRTM with a grid size of $30 \mathrm{~m} \times 30 \mathrm{~m}$. The elevation in the area of study varies between $113 \mathrm{~m}$ to $1,180 \mathrm{~m}$.

\subsubsection{Curvature (C)}

Curvature is used to identify zones that exhibit proneness to landslides[19]. Curvature is derived from DEM using GIS. Analysis of curvature enables categorization of areas into concave, convex, and flat.

\subsubsection{Vegetation Index (NDVI)}

NDVI is used to measure the vegetation characteristics of the area [21]. The decrease in land cover causes an increase in the image's local brightness and can be very well represented by Normalized Difference Vegetation Index (NDVI) [22]. The NVDI map is generated based on Landsat 8 satellite images. The NDVI value can be computed by using the equation below [23].

$N D V I=(N I R-V I S) /(N I R+V I S)$

Where:

NDVI = a measure of sensitive vegetation using the spectral energy difference reflected by vegetation canopy at a wavelength of electromagnetic spectrum red and nearinfrared with values ranging from -1 to $1[24]$.

NIR = spectral reflectance measurement acquired in the infrared wave region (band 4).

VIS = spectral reflectance measurement acquired in the red visible wave region (band 5) 


\subsubsection{Geology}

It is one of the driving factors of landslides [10], [25]. The Bulncong subwatershed's Geology is characterized by Raung volcanic rocks, Bogor formation, diorite, Ringgit formation, Menuran formation, and Leprak formation. The Bangor Formation consists of pyroclastic rocks, characterized by pyroclastic rocks, characterized by alternating sandstones and tuffaceous breccias, and intercalation of polymeric conglomerates on sandstones. [26]. The breccias generally have a dacitic pumice component with a thickness of up to $3 \mathrm{~m}$. The tuffaceous sandstone is typically very coarse-grained, composed mainly of volcanic rock fragments. These rocks are generally less compact and friable. Many diagnostic layers are calcareous sandstone, showing sedimentary structures of graded bedding and parallel bedding. The Menuran Formation is a distal turbidite deposit on the upper bathyal environment influenced by strong volcanic activity. The Pacalan limestone in the area Klabang, Bondowoso, which position relative to the southwest. Generally contains more abundant and coarse-grained bioclasts [26].

\subsection{Inventory and Field Observation at Landslide Sites for Landslide Causative Factors Reclassification}

The purpose of the inventory of landslides is to identify the locations of landslides. Further, it is used to analyze the relationship between landslide occurrence and the causing factors and gain the relationship between the landslides' occurrence in the past and probable occurrences in the future. Field surveys and extensive observation were carried out in the area of study to produce detailed, reliable landslide maps. acquired the data used in the inventory for landslide mapping from several sources, namely field data collection, satellite images, and spatial data from the Technical Operating Unit of Water Resources Management (UPT PSDA) Sampean Baru. The map of landslide locations was acquired by ground checking and Google Earth was used to get coordinate points of the locations. DEM Aster map with $30 \mathrm{~m} \times$ $30 \mathrm{~m}$ resolution downloaded from USGS official website (https://earthexplorer.usgs.gov) is used to derive slope, elevation, curvature, and aspect data. Peta Citra lansat 8 akan menghasilkan peta NDVI. Geology spatial data, land use data, and river networks data, all acquired from UPT PSDA Sampean Baru, were used to generate maps of land use, soil types, and distance to rivers. The landslide-causing factors were then reclassified. Geographical Information System was used to ease spatial information presentation, especially related to landslide susceptibility, and to analyze Information to identify areas susceptible to landslides. 


\subsection{Determination of Weights of Factors by FR Method}

For landslide susceptibility mapping, this research uses a weighting algorithm with a Frequency Ratio (FR) approach, which automatically determines the weight of the factors contributing to the landslides. One of the methods widely used in weighting landslide susceptibility is the Frequency Ratio (FR) [8]-[11], [17]. This method is a simple probabilistic model widely used in landslide susceptibility studies. FR is defined as the ratio of the area where landslides occurred in the total study area and is also the ratio of the probabilities of a landslide occurrence to a nonoccurrence for a given attribute [27]. FR shows the relationship between spatial distribution observed landslide locations and landslide causative factors. The equation below shows the mathematical formula of FR [23].

$F R=\frac{\text { (Landslide points in factor class/Total landslide points) }}{\text { (Factor class area/Total area) }}$

\subsection{Determination and Mapping of Landslide Susceptibility Indices (LSI)}

The extent of landslide susceptibility is proportional to the landslide occurrences [27]. It means that the more frequently landslides occur in an area, the more landslidesusceptible it is. Likewise, the less frequently landslides occur in an area, the less landslidesusceptible it is. The computation of Landslide Susceptibility Indices (LSI) by using the FR method is conducted by summing the frequency ratios from all factors, namely: land cover (LC), distance to the river (DR), geology $(\mathrm{G})$, aspect (A), slope (S), elevation (E), curvature (C), and vegetation index (NDVI), as shown in equation (3).

$L S I=F R_{L C}+F R_{D R}+F R_{G}+F R_{A}+F R_{S}+F R_{E}+F R_{C}+F R_{n d v i}$

The Geographical Information System (GIS) software carries out the overlay involving the landslide causative factors to map the landslide susceptibility. The FR scores from all factors are then entered so that the modified modeling can be run [28]. This operation results in a map of the distribution of landslide susceptibility categorized into five levels: very high, high, moderate, low, and very low.

\subsection{Validation of the Model by Comparison of Area under Curve (AUC).}

The Area Under Curve (AUC) is presented to measure the difference in performance between methods used. AUC is a measure widely used for prediction models in natural hazard assessment[29]. The value of AUC varies from 0.5 to 1. A model with an AUC value Higher than 0.5 is considered acceptable. A model with AUC in the range of 1.0 to 0.9 is 
considered extraordinary, 0.9 to 0.8 very good, $0.8-0.7$ acceptable [30].

\section{Results and Discussions}

Results and discussions describe factors that drive the landslides, landslide susceptibility Map, and validation of the landslide susceptibility map

\subsection{Factors that Drive the Landslides}

As the maps in Figure 3a-f show, each of the land use, distance to drainage, geology, NDVI, slope, and elevation is classified into six classes. In contrast, the aspect is classified into ten classes, as shown in Figure $3 \mathrm{~g}$. The curvature is classified into three classes, as shown in Figure $3 h$.

a

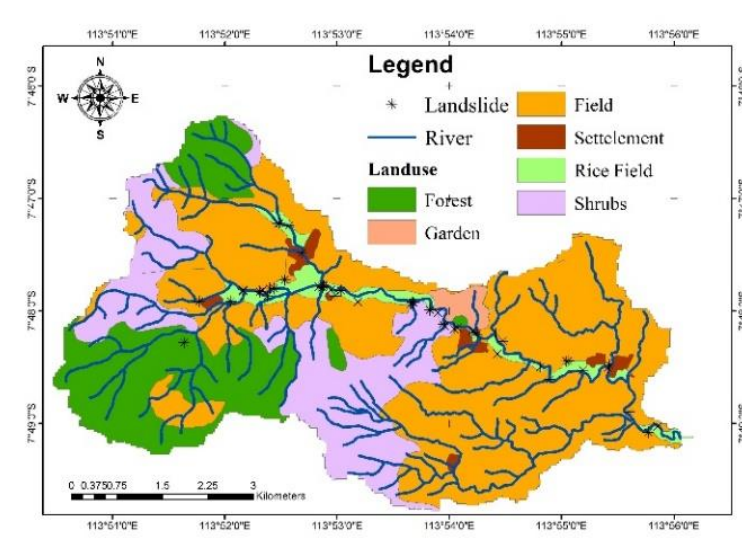

c

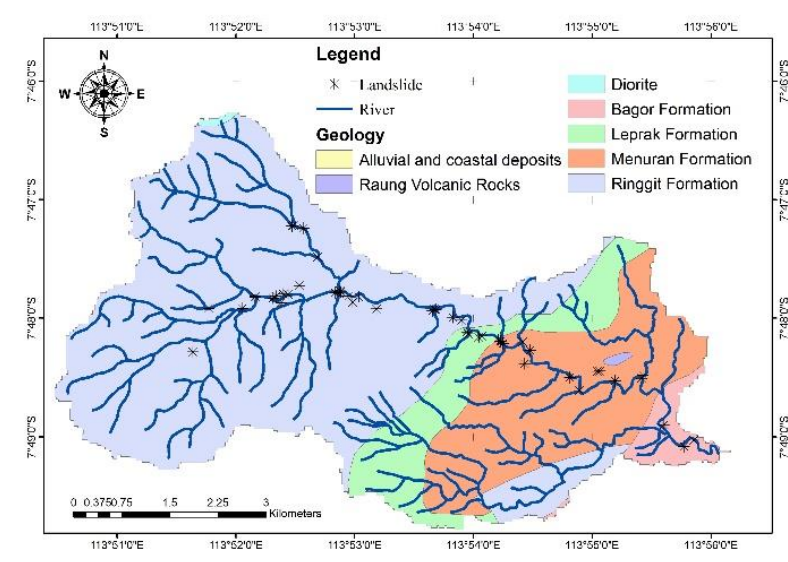

$\mathrm{e}$

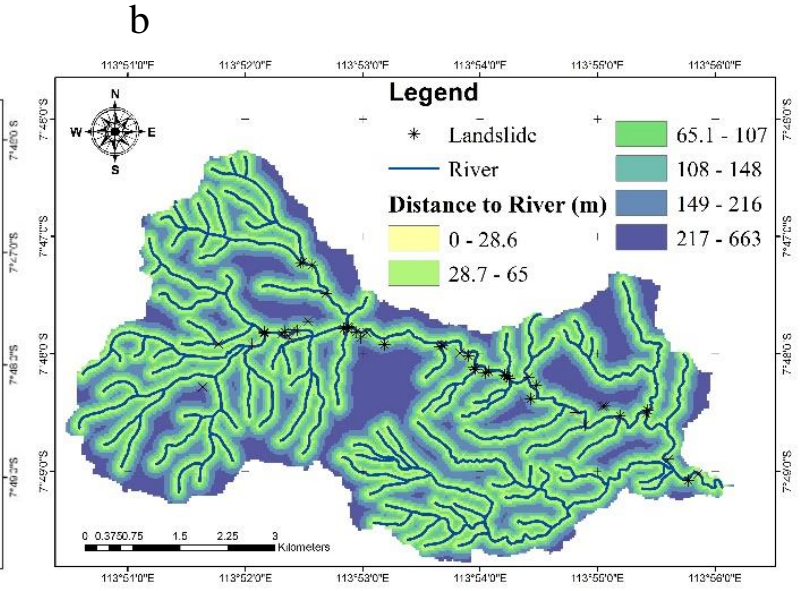

d

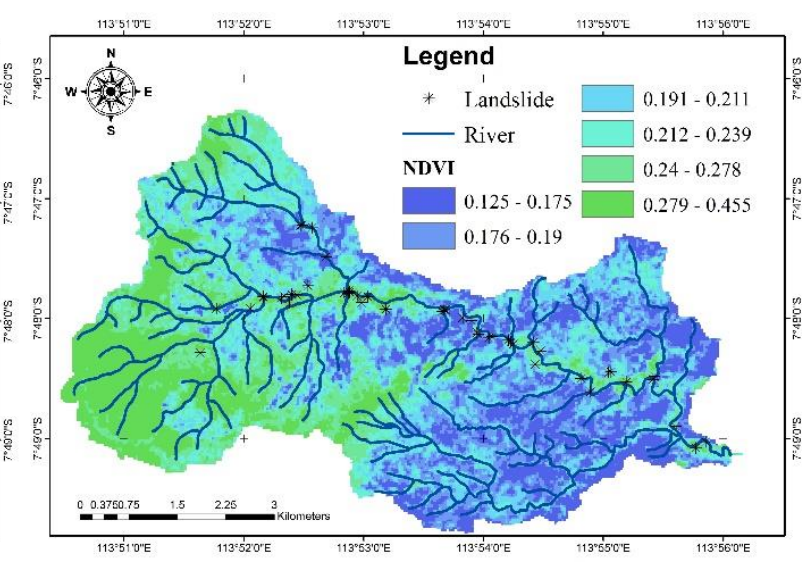

f 

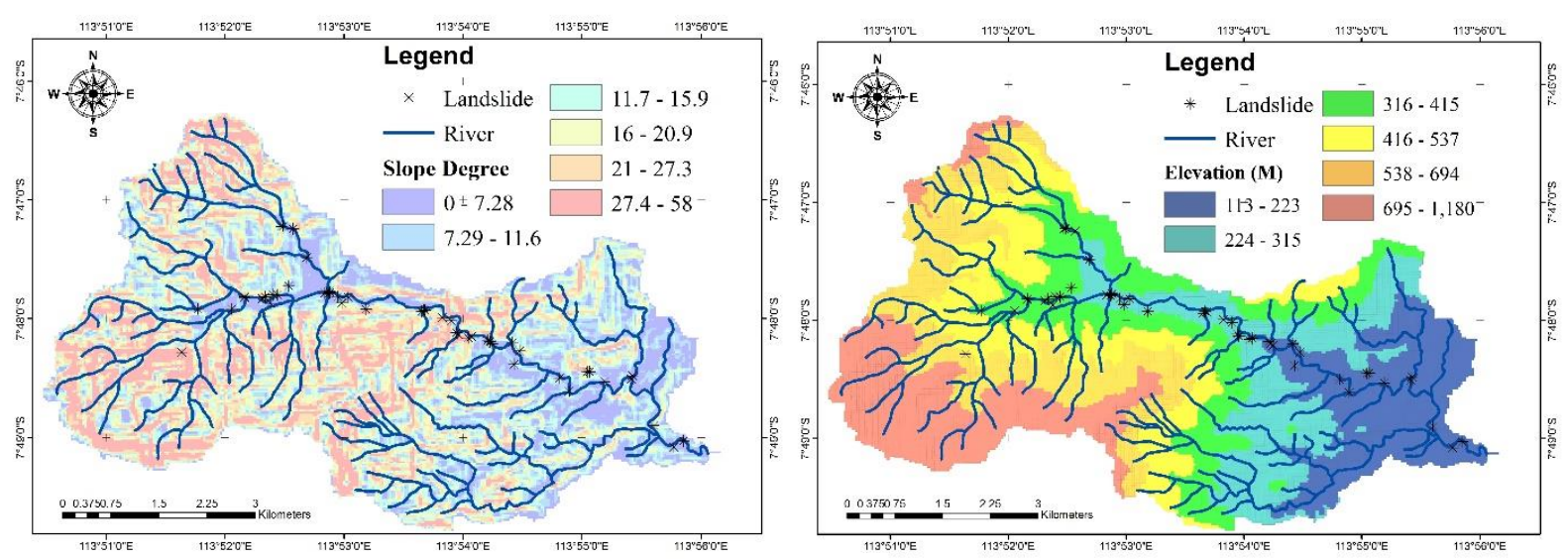

g

$\mathrm{h}$
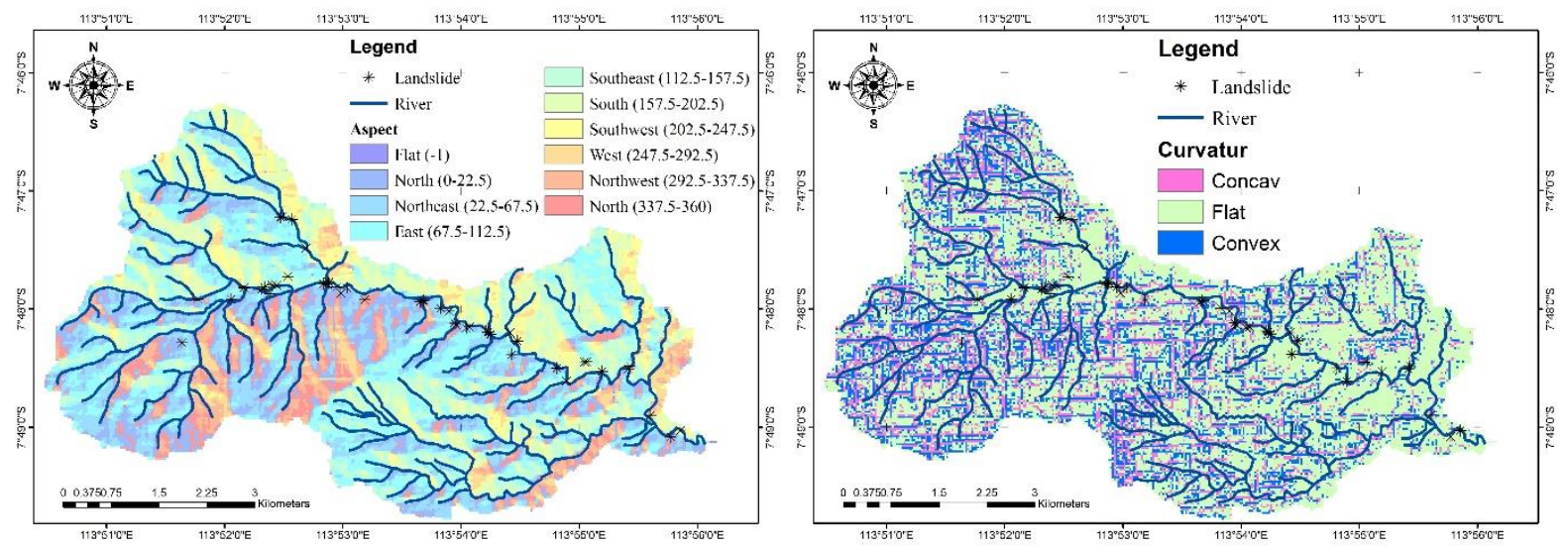

Source : Research Document (2020)

Figure 3. Thematic map of the study area a. land use, b. distance to drainage, c. geology, d. NDVI, e. slope, f. elevation, g. aspect, dan h. curvature.

After conditioning all factors, FR values of all classes are computed. A combined approach between FR values this study landslide susceptibility as bivariate statistics method and geospatial technique. FR is used to compute the correlation between landslide occurrences and the driving factors. Table 1 shows the relationships among multiple driving factors of landslides, the subclasses, and the landslide occurrences in the Bluncong subwatershed. Eight factors with the highest frequency ratio are land use, aspect, distance to the river, slope, elevation, NDVI, geology, and curvature, as shown in Figure 4. There is a direct positive relationship between FR and the probability of landslide occurrence. This relationship is also indicated in Table 1 , in which the frequency ratio higher than 1 indicates a higher correlation, whereas the frequency ratio lower than 1 indicates lower correlation.

In the land-use factor, rice field, settlement, and garden show higher FR values than other classes. It means that the landslides most frequently occurred in the past and, hence, 
probably occur in the future, in the areas with these uses. The High-frequency ratio of landslides in the settlement should raise concern due to the residents' corresponding harm. The classes in the aspect factor show a wide occurrence of landslides. In the area of study, next to a bridge, the road is ascending in the northwest direction. Most of the residential buildings and agricultural lands are heading northeast, south, and southwest. It covers more than $50 \%$ of the distribution of landslides. The landslide sites are typically distributed along the vicinity of rivers. As for the slope factor, the slope that ranges between $0^{\circ}-7.28^{\circ}$ shows landslide distribution with a significantly higher frequency ratio than other classes. The areas with this class of slope are the landslide's end parts, hence becoming the accumulation zones. The slope class of $21-27,3^{\circ}$, which indicates a steep slope, is also influential to the landslide. In the curvature factor, the landslides are distributed in flat and concave surfaces, but the concave areas are higher than those in flat areas.

On the other hand, convex slopes are more stable than concave ones because the overflow in convex is distributed more evenly. In concave slopes, the water is concentrated in the bottom part. In the geology factor, Bagor formation and Menuran formation can drive the landslides, as shown in Table 1 . The combination of sands mixed with breccia and limestones in these formations form crumbly structures that have high landslide potential.

Table 1. Frequency Ratio (FR) of Each Class within Each Factor in the Study Area

\begin{tabular}{|c|c|c|c|c|c|c|}
\hline Faktor & Classes & Domain Pixel & $\%$ Domain Pixel & Landslide & $\%$ Landslide pixel & FR \\
\hline \multirow[t]{7}{*}{ Land use } & Forest & 7738.00 & 19.48 & 2.00 & 4.17 & 0.21 \\
\hline & Garden & 506.00 & 1.27 & 1.00 & 2.08 & 1.64 \\
\hline & Field & 21216.00 & 53.41 & 15.00 & 31.25 & 0.59 \\
\hline & Settlement & 647.00 & 1.63 & 4.00 & 8.33 & 5.12 \\
\hline & Rice field & 1651.00 & 4.16 & 23.00 & 47.92 & 11.53 \\
\hline & Shrubs & 7968.00 & 20.06 & 3.00 & 6.25 & 0.31 \\
\hline & & 39726.00 & 100.00 & 48.00 & 100.00 & 19.39 \\
\hline \multirow[t]{11}{*}{ Aspect } & Flat & 22.00 & 0.06 & 0.00 & 0.00 & 0.00 \\
\hline & North & 4325.00 & 10.88 & 5.00 & 10.42 & 0.96 \\
\hline & Northeast & 7272.00 & 18.29 & 10.00 & 20.83 & 1.14 \\
\hline & East & 6863.00 & 17.26 & 5.00 & 10.42 & 0.60 \\
\hline & Southeast & 6056.00 & 15.23 & 6.00 & 12.50 & 0.82 \\
\hline & South & 5962.00 & 14.99 & 10.00 & 20.83 & 1.39 \\
\hline & Southwest & 2543.00 & 6.40 & 5.00 & 10.42 & 1.63 \\
\hline & West & 1896.00 & 4.77 & 2.00 & 4.17 & 0.87 \\
\hline & Northwest & 2290.00 & 5.76 & 1.00 & 2.08 & 0.36 \\
\hline & North & 2535.00 & 6.38 & 4.00 & 8.33 & 1.31 \\
\hline & Sum & 39764.00 & 76.70 & 48.00 & 75.00 & 9.08 \\
\hline \multirow[t]{7}{*}{ Distance to drainage } & $0-28.6$ & 4064.00 & 10.22 & 23.00 & 47.92 & 4.69 \\
\hline & $28.6-65$ & 10788.00 & 27.13 & 18.00 & 37.50 & 1.38 \\
\hline & $65.1-107$ & 6844.00 & 17.21 & 2.00 & 4.17 & 0.24 \\
\hline & $108-148$ & 5461.00 & 13.73 & 2.00 & 4.17 & 0.30 \\
\hline & $149-216$ & 7079.00 & 17.80 & 3.00 & 6.25 & 0.35 \\
\hline & $217-663$ & 5528.00 & 13.90 & 0.00 & 0.00 & 0.00 \\
\hline & Sum & 39764.00 & 100.00 & 48.00 & 100.00 & 6.97 \\
\hline
\end{tabular}




\begin{tabular}{|c|c|c|c|c|c|c|}
\hline Faktor & Classes & Domain Pixel & $\%$ Domain Pixel & Landslide & $\%$ Landslide pixel & FR \\
\hline \multirow{7}{*}{ Slope } & $0-7.28$ & 6376.00 & 16.03 & 21.00 & 43.75 & 2.73 \\
\hline & $7.29-11.6$ & 6511.00 & 16.37 & 7.00 & 14.58 & 0.89 \\
\hline & $11.7-15.9$ & 6798.00 & 17.10 & 5.00 & 10.42 & 0.61 \\
\hline & 16- 20.9 & 6728.00 & 16.92 & 4.00 & 8.33 & 0.49 \\
\hline & $21-27.3$ & 6647.00 & 16.72 & 8.00 & 16.67 & 1.00 \\
\hline & 27.458 & 6704.00 & 16.86 & 3.00 & 6.25 & 0.37 \\
\hline & Sum & 39764.00 & 100.00 & 48.00 & 100.00 & 6.09 \\
\hline \multirow[t]{7}{*}{ Elevation } & $113-223$ & 6642.00 & 16.70 & 17.00 & 35.42 & 2.12 \\
\hline & $224-315$ & 6671.00 & 16.78 & 17.00 & 35.42 & 2.11 \\
\hline & $316-415$ & 6646.00 & 16.71 & 13.00 & 27.08 & 1.62 \\
\hline & $416-537$ & 6652.00 & 16.73 & 0.00 & 0.00 & 0.00 \\
\hline & $537-694$ & 6623.00 & 16.66 & 1.00 & 2.08 & 0.13 \\
\hline & $694-1175$ & 6530.00 & 16.42 & 0.00 & 0.00 & 0.00 \\
\hline & Sum & 39764.00 & 100.00 & 48.00 & 100.00 & 5.98 \\
\hline \multirow[t]{7}{*}{ NDVI } & $0.125-0.185$ & 10757.00 & 27.05 & 3.00 & 6.25 & 0.23 \\
\hline & $0.186-0.219$ & 11265.00 & 28.33 & 16.00 & 33.33 & 1.18 \\
\hline & $0.22-0.256$ & 7792.00 & 19.59 & 16.00 & 33.33 & 1.70 \\
\hline & $0.257-0.299$ & 5631.00 & 14.16 & 11.00 & 22.92 & 1.62 \\
\hline & $0.3-0.353$ & 2817.00 & 7.08 & 2.00 & 4.17 & 0.59 \\
\hline & $232667-415208$ & 1506.00 & 3.79 & 0.00 & 0.00 & 0.00 \\
\hline & Sum & 39768.00 & 100.00 & 48.00 & 100.00 & 5.32 \\
\hline \multirow[t]{7}{*}{ Geology } & Batuan Vulkanik Raung & 58.00 & 0.15 & 0.00 & 0.00 & 0.00 \\
\hline & Formasi Bagor & 1120.00 & 2.82 & 3.00 & 6.25 & 2.22 \\
\hline & Diorit & 72.00 & 0.18 & 0.00 & 0.00 & 0.00 \\
\hline & Formasi Ringgit & 25500.00 & 64.13 & 28.00 & 58.33 & 0.91 \\
\hline & Formasi Menuran & 8815.00 & 22.17 & 13.00 & 27.08 & 1.22 \\
\hline & Formasi Leprak & 4199.00 & 10.56 & 4.00 & 8.33 & 0.79 \\
\hline & Sum & 39764.00 & 100.00 & 48.00 & 100.00 & 5.14 \\
\hline \multirow[t]{4}{*}{ Curvature } & Concave & 7612.00 & 19.14 & 12.00 & 25.00 & 1.31 \\
\hline & Flat & 24587.00 & 61.83 & 33.00 & 68.75 & 1.11 \\
\hline & Convex & 7565.00 & 19.02 & 3.00 & 6.25 & 0.33 \\
\hline & Sum & 39764.00 & 100.00 & 48.00 & 100.00 & 2.75 \\
\hline
\end{tabular}

Source : Research Document (2020)

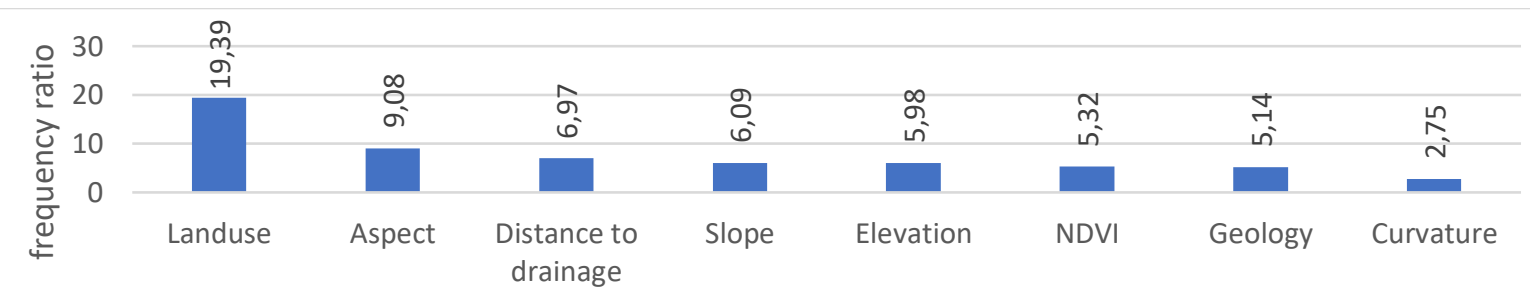

Factor

Source : Research Document (2020)

Figure 4. Frequency Ratio of the Causative Factors

\subsection{Landslide Susceptibility Map}

The frequency ratios derived for each class's causative factors are then combined in the GIS to develop the landslide susceptibility index (LSI) map, as shown in Figure 5. The LSI map's landslide susceptibility is reclassified into five classes: very low, low, moderate, high, and very high. This study shows that $30.01 \%$ of the study area has very low susceptibility, $29.29 \%$ have low susceptibility, $20.47 \%$ have moderate susceptibility, $11.20 \%$ have high susceptibility, and $9.08 \%$ have very high susceptibility. 


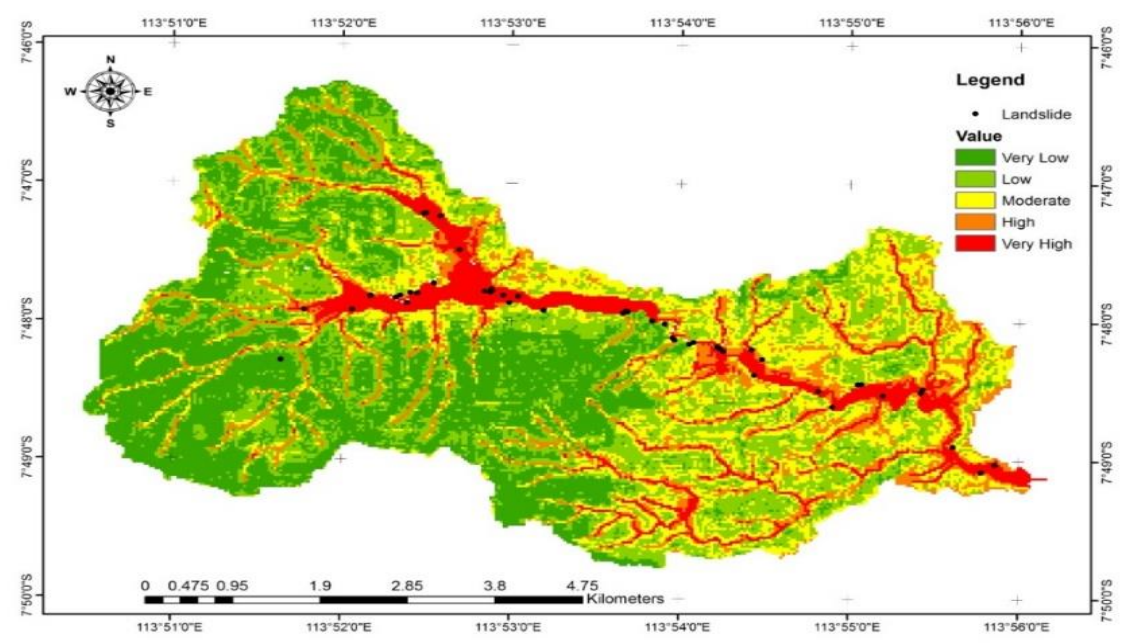

Source : Research Document (2020)

Figure 5. Landslide Susceptibility Map of Bluncong Subwatershed

\subsection{Validation of The Landslide Susceptibility Map}

The accuracy assessment method was performed by comparing the existing landslide dataset with landslide susceptibility results, as shown in Figure 6.

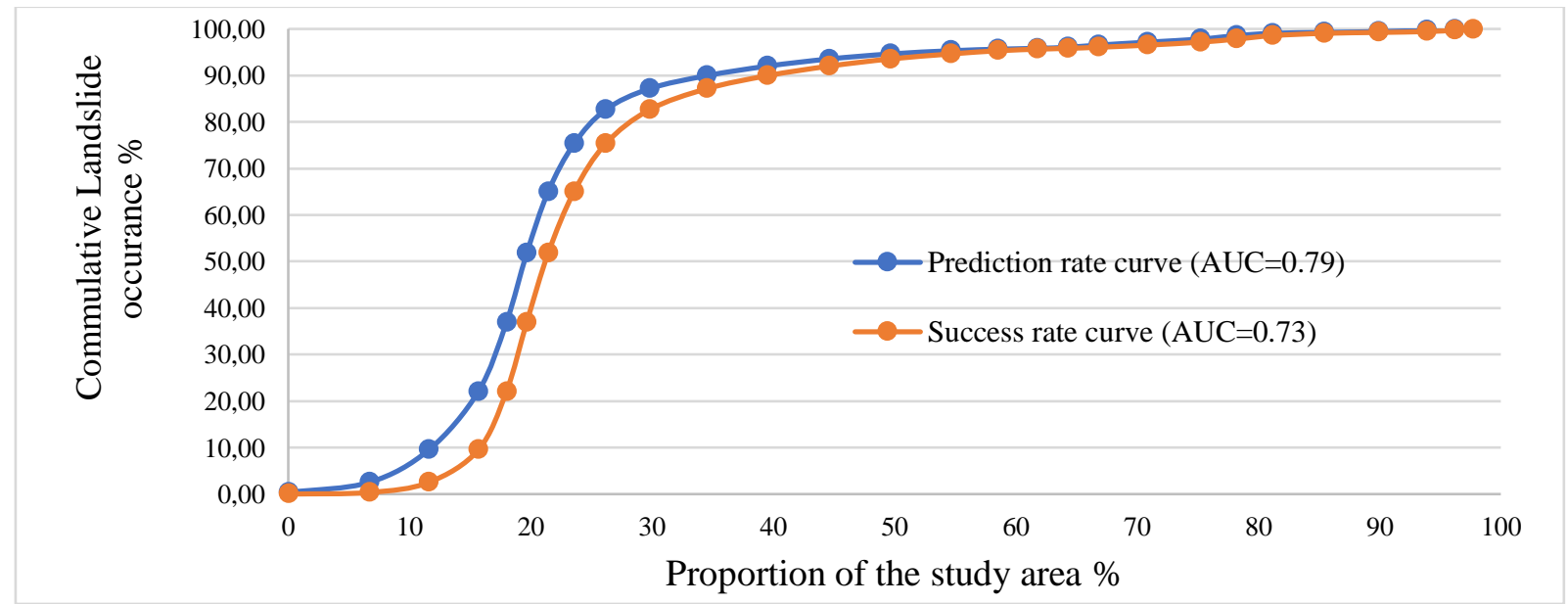

Source : Research Document (2020)

Figure 6. ROC Curves using Validation and Training Dataset

The success rate curve and the prediction rate curve as shown in Figure 6 are used to validate the landslide susceptibility map shown in Figure 5. These curves are Receiver Operating Characteristics Curve (ROC), a popular tool to evaluate the result's accuracy because of its generality and features. The FR model generated in this study shows Area Under AUC of the success rate and the prediction rate are 0.79 and 0.73 , respectively. This mapping can be used to detect the location of landslides early. This mapping can be used to detect the location of landslides early, although this AUC value still needs to be improved. 


\section{Conclusion and Suggestion}

\subsection{Conclusion}

The remote sensing and GIS, combined with the Frequency Ratio approach, have effectively map landslide susceptibility. The accuracy of the FR, calculated based on AUC, is 0.79 , which shows that the mapping result is acceptable.

The most influential factor driving the landslides is land use $(19.39 \%)$. The most dominant classes are agricultural use, settlement use, and field use. Also, the factor of aspect also controls the spatial distribution of the landslides in the study area. The landslide intensity increases near rivers and paddy fields.

The landslide susceptibility map in Bluncong Subwatershed shows that $9.08 \%$ of the area has very high susceptibility. Relevant institutions can use the landslide susceptibility map developed in this study to formulate and implement landslide mitigation steps.

\subsection{Suggestion}

To get a better model of landslides, we can do further modeling by applying a weighting method with machine learning or finding other factors that are more influential in triggering landslides. 


\section{References}

[1] Y. Wang, Q. Lin, and P. Shi, 'Spatial pattern and influencing factors of landslide casualty events', J. Geogr. Sci., vol. 28, no. 3, pp. 259-274, 2018, doi: 10.1007/s11442018-1471-3.

[2] E. N. C. Perera, D. T. Jayawardana, P. Jayasinghe, R. M. S. Bandara, and N. Alahakoon, 'Direct impacts of landslides on socio-economic systems: a case study from Aranayake, Sri Lanka', Geoenvironmental Disasters, vol. 5, no. 1, 2018, doi: 10.1186/s40677-018-0104-6.

[3] H. D. Skilodimou, G. D. Bathrellos, E. Koskeridou, K. Soukis, and D. Rozos, 'Physical and anthropogenic factors related to landslide activity in the northern Peloponnese, Greece', Land, vol. 7, no. 3, 2018, doi: 10.3390/land7030085.

[4] S. Bahrami, B. Rahimzadeh, and S. Khaleghi, 'Analyzing the effects of tectonic and lithology on the occurrence of landslide along Zagros ophiolitic suture: a case study of Sarv-Abad, Kurdistan, Iran', Bull. Eng. Geol. Environ., vol. 79, no. 3, pp. 1619-1637, 2020, doi: 10.1007/s10064-019-01639-3.

[5] E. Amir Yazdadi and E. Ghanavati, 'Landslide Hazard Zonation by using AHP ( Analytical Hierarchy Process ) model in GIS ( Geographic Information System ) Environment ( Case study: Kordan Watershed ) Landslide Hazard Zonation by using AHP ( Analytical Hierarchy Process ) model in GIS ( Geo', vol. 2, no. February, pp. 24-39, 2016.

[6] J. M. Mustafa, S. Sirojuzilam, and N. Sulistiyono, 'Analisis Tingkat Kerawanan Longsor Dengan Integrasi Analytical Hierarchy Process dan Pemodelan Spasial Sistem Informasi Geografis di Kabupaten Aceh Tenggara', J. Serambi Eng., vol. 4, no. 1, p. 471, 2019, doi: 10.32672/jse.v4i1.981.

[7] G. Yalcin and Z. Akyurek, 'Analysing Flood Vulnerable Areas With Multicriteria Evaluation', Methods, pp. 1-6, 2000.

[8] S. Lee and B. Pradhan, 'Landslide hazard mapping at Selangor, Malaysia using frequency ratio and logistic regression models', Landslides, vol. 4, no. 1, pp. 33-41, 2007, doi: 10.1007/s10346-006-0047-y.

[9] S. Mondal and R. Maiti, 'Integrating the Analytical Hierarchy Process (AHP) and the frequency ratio (FR) model in landslide susceptibility mapping of Shiv-khola watershed, Darjeeling Himalaya', Int. J. Disaster Risk Sci., vol. 4, no. 4, pp. 200-212, 2013, doi: 10.1007/s13753-013-0021-y.

[10] H. Khan, M. Shafique, M. A. Khan, M. A. Bacha, S. U. Shah, and C. Calligaris, 'Landslide susceptibility assessment using Frequency Ratio, a case study of northern Pakistan', Egypt. J. Remote Sens. Sp. Sci., vol. 22, no. 1, pp. 11-24, 2019, doi: 10.1016/j.ejrs.2018.03.004. 
[11] T. D. Acharya and D. H. Lee, 'Landslide Susceptibility Mapping using Relative Frequency and Predictor Rate along Araniko Highway', KSCE J. Civ. Eng., vol. 23, no. 2, pp. 763-776, 2019, doi: 10.1007/s12205-018-0156-х.

[12] H. Nugraha, D. Wacano, G. A. Dipayana, A. Cahyadi, B. W. Mutaqin, and A. Larasati, 'Geomorphometric Characteristics of Landslides in the Tinalah Watershed, Menoreh Mountains, Yogyakarta, Indonesia', Procedia Environ. Sci., vol. 28, no. SustaiN 2014, pp. 578-586, 2015, doi: 10.1016/j.proenv.2015.07.068.

[13] R. K. Dahal, 'Landslide hazard mapping in GIS', vol. 53, pp. 63-91, 2017.

[14] K. C. Devkota et al., 'Landslide susceptibility mapping using certainty factor, index of entropy and logistic regression models in GIS and their comparison at MuglingNarayanghat road section in Nepal Himalaya', Nat. Hazards, vol. 65, no. 1, pp. 135165, 2013, doi: 10.1007/s11069-012-0347-6.

[15] M. Ercanoglu and C. Gokceoglu, 'Assessment of landslide susceptibility for a landslide-prone area (north of Yenice, NW Turkey) by fuzzy approach', Environ. Geol., vol. 41, no. 6, pp. 720-730, 2002, doi: 10.1007/s00254-001-0454-2.

[16] D. S. Fernández and M. A. Lutz, 'Urban flood hazard zoning in Tucumán Province, Argentina, using GIS and multicriteria decision analysis', Eng. Geol., vol. 111, no. 1-4, pp. 90-98, 2010, doi: 10.1016/j.enggeo.2009.12.006.

[17] A. D. Regmi et al., 'Application of frequency ratio, statistical index, and weights-ofevidence models and their comparison in landslide susceptibility mapping in Central Nepal Himalaya', Arab. J. Geosci., vol. 7, no. 2, pp. 725-742, 2014, doi: 10.1007/s12517-012-0807-z.

[18] C. Xu, X. Xu, X. Tan, and R. Yuan, 'Landslide Hazard Mapping Using GIS and Weight of Evidence Model in Qingshui River Watershed of 2008 Wenchuan Earthquake Struck Region', no. May 2014, 2012, doi: 10.1007/s12583-012-0236-7.

[19] F. Mancini, C. Ceppi, and G. Ritrovato, 'GIS and statistical analysis for landslide susceptibility mapping in the Daunia area, Italy', Nat. Hazards Earth Syst. Sci., vol. 10, no. 9, pp. 1851-1864, 2010, doi: 10.5194/nhess-10-1851-2010.

[20] S. Moradi and M. Rezaei, 'A GIS-based comparative study of the analytic hierarchy process, bivariate statistics and frequency ratio methods for landslide susceptibility mapping in part of the Tehran metropolis , Iran', vol. 4, no. 1, pp. 45-61, 2014.

[21] D. Sudiana and E. Diasmara, 'Analisis Indeks Vegetasi menggunakan Data Satelit', Semin. Intell. Technol. Its Appl., pp. 423-428, 2008.

[22] A. R. Falahnsia, 'VEGETASI DENGAN METODE SKORING MENGGUNAKAN CITRA SATELIT DI', pp. 400-416, 2014. 
[23] K. Ullah, J. Zhang, and J. Z. Id, 'GIS-based flood hazard mapping using relative frequency ratio method: A case study of panjkora river basin, eastern Hindu Kush, Pakistan', PLoS One, vol. 15, no. 3, pp. 1-18, 2020, doi: 10.1371/journal.pone.0229153.

[24] A. Nertan, G. Stancalie, and F. Serban, 'Agricultural Drought Monitoring Using Satellite - Based Products in Romania', no. Ictrs, pp. 100-106, 2014, doi: 10.5220/0005421901000106.

[25] W. M. Abdulwahid and B. Pradhan, 'Landslide vulnerability and risk assessment for multi-hazard scenarios using airborne laser scanning data (LiDAR)', Landslides, vol. 14, no. 3, pp. 1057-1076, 2017, doi: 10.1007/s10346-016-0744-0.

[26] A. H. Harsolumakso, D. Noeradi, A. Rudyawan, D. Amiarsa, S. Wicaksono, and A. A. Nurfarhan, 'Geology of the Eastern Part of the Volcanic-Kendeng Zone of East Java: Stratigraphy, Structures and Sedimentation Review from Besuki and Situbondo Areas', J. Geol. dan Sumberd. Miner., vol. 20, no. 3, p. 143, 2019, doi: 10.33332/jgsm.geologi.v20i3.465.

[27] B. Pradhan and S. Lee, 'Landslide susceptibility assessment and factor effect analysis: backpropagation artificial neural networks and their comparison with frequency ratio and bivariate logistic regression modelling', Environ. Model. Softw., vol. 25, no. 6, pp. 747-759, 2010, doi: 10.1016/j.envsoft.2009.10.016.

[28] E. A. C. Abella and C. J. Van Westen, 'Generation of a landslide risk index map for Cuba using spatial multi-criteria evaluation', Landslides, vol. 4, no. 4, pp. 311-325, 2007, doi: 10.1007/s10346-007-0087-y.

[29] S. Chauhan, M. Sharma, and M. K. Arora, 'Landslide susceptibility zonation of the Chamoli region, Garhwal Himalayas, using logistic regression model', Landslides, vol. 7, no. 4, pp. 411-423, 2010, doi: 10.1007/s10346-010-0202-3.

[30] D. W. Hosmer and S. Lemeshow, Applied Logistic Regression, Second. Canada: A Wiley-Interscience Publication, 2000. 